\title{
Socialist television drama, newspaper critics and the battle of ideas during the crisis of Britain's post-war settlement
}

\author{
Author: Steven Fielding \\ Journal: Twentieth Century British History \\ Accepted for Publication: 1 February 2019
}

More than ever, ideas matter to political historians: many have now taken an 'ideational turn' ${ }^{1}$ This is especially true of students of the 1970 s, the decade when a fierce ideological battle with huge consequences for the future raged over Britain's ailing post-war settlement. By keeping the profit motive intact and leaving untouched most bastions of established power, but expanding the role of government and giving organized labour a bigger voice, some believed the settlement had permanently placed Britain somewhere between socialism and the free market. ${ }^{2}$ Sustained by what Paul Addison described as a limited 'Whitehall consensus', the settlement nonetheless remained the subject of keen ideological debate. ${ }^{3}$ Economic growth and popular affluence however meant that those who wanted to firmly wrest it towards socialism or the free market were largely excluded from influence within government. But once Britain's mounting economic problems were compounded by the quadrupling of the price of oil in 1973-4 and the country found itself in an inflation-fueled recession, the existential questions long asked by the far-left and radical right won new audiences beyond Whitehall. ${ }^{4}$

If measured in strictly parliamentary terms it was the right that won this battle of ideas. Margaret Thatcher's election as Prime Minister in 1979 certainly marked a turning point in public policy. In office she laid the foundations for a new 
kind of settlement, a different 'Whitehall consensus', part of an international shift from ideas that favoured state intervention towards those supportive of economic liberalisation. ${ }^{5}$ This has led to an understandable historiographical emphasis on the ideas which informed Thatcher's winning strategy and shaped measures she pursued in office. ${ }^{6}$ Betraying the roots of the 'ideational turn' in a state-centric historical institutionalism, this work also focuses on elite figures who ultimately contributed to party and government policy, giving sustenance to narratives that emphasise their agency in the breaking of one settlement and the making of another. ${ }^{7}$ The very weight of this literature contributes to the sense that the triumph of 'Thatcherism' was somehow inevitable. ${ }^{8}$

As with most historical processes however other outcomes were possible. During the 1970s many socialists considered they might prevail: even members of Thatcher's Shadow Cabinet believed, 'Society was moving more left'. ${ }^{9}$ The growing influence of left-wing activists in the Labour party meant the February 1974 general election saw Harold Wilson enter Downing Street with a manifesto promising, 'a fundamental and irreversible shift in the balance of power and wealth in favour of working people'. Indeed, Tony Benn, who helped shape that manifesto already thought, 'Power has shifted to people on the shop floor'. ${ }^{10}$ Once in office Wilson and his successor James Callaghan nonetheless disavowed this pledge and tried to maintain the post-war settlement by pursuing measures that forced unemployment up and standards of living down. Despite that, Labour activists continued to argue for policies designed to transcend the settlement from the left. ${ }^{11}$ Benn in particular remained convinced Britain's economic troubles necessitated a 'new consensus' based on workers' control of industry and a massive expansion of government 
intervention. He used his position as a Cabinet Minister to as he put it 'educate' the public through the traditional political means of making speeches that outlined his case. $^{12}$

Historians have yet to systematically and comprehensively explain why the ideas of the radical right, rather than those of the far-left, were the ones that came to be applied in government. It is nonetheless clear that this was not necessarily due to the merits of the ideas themselves. As Sheri Berman notes: 'new ideas do not achieve prominence on their own but must be championed by carriers or entrepreneurs, individuals or groups capable of persuading others to reconsider the ways they think and act'. ${ }^{13}$ It is significant therefore that in what Peter Hall called an emerging 'marketplace for ideas', those associated with the radical right were advocated by prominent media commentators, members of City brokerage houses and a burgeoning number of newly-formed thinktanks - as well as the leader of the Conservative party. ${ }^{14}$ In contrast, socialist ideas had so few advocates Hall did not consider them worthy of mention. Labour's parliamentary leadership undoubtedly did its best to refute Benn and his allies who were regularly defamed in the press and had no friends to speak of in the City. In that hostile institutional context a few speeches from an embattled socialist Cabinet minister were never likely to make much of an impression.

Hall wanted to show how a 'societal debate' changed government economic thinking from the Keynesianism that underpinned the post-war settlement to the monetarism applied by Thatcher. Participants in this 'debate' comprised elite figures because Hall was only concerned with the specialised work of policy-making. While he recognised that winning elections largely decided which policies were applied in 
office Hall was nonetheless uninterested in ideas that prevailed in the wider national culture beyond his 'marketplace'. Popular ideas necessarily have a less distinct character to those associated with the purposive notions underpinning the creation of policy. But culture still provides what Berman calls 'broad guidelines' for popular politics, and is the terrain over which all parties must fight if they are to achieve power. ${ }^{15}$ Consequently, historians wishing to properly understand the politics of the 1970s need to focus as much on popular culture as they do on elite policy-making.

Historians of earlier periods long ago granted culture a constitutive ideational role. As E.P. Thompson suggested, if economic factors influenced how ordinary people saw their situation culture played a significant interceding function. ${ }^{16}$ Social scientists are also now inclined to give culture an important political role given it is the location where 'different subjects, subjectivities and modes of calculation come to be naturalised' ${ }^{17}$ As the sociologist Anne Swidler put it, culture helps shape 'a repertoire or "tool kit" of habits, skills and styles from which people construct strategies of action'. Swidler nonetheless recognised that any national culture contains a diverse set of potential guides to action, meaning its influence will 'vary across time and historical situation' ${ }^{18}$ Given this, and that Stuart Hall's early and otherwise highly influential analysis of 'Thatcherism' stressed how far changes in popular ideas explained rising support for the radical right, it is ironic so few political historians of the 1970s have taken culture seriously as an ideational resource. ${ }^{19}$ There are however signs this situation is changing. In particular Dean Blackburn's recent account of how socialist ideas underpinned much of Penguin Book's nonfiction list shows that the battle of ideas was keenly fought well beyond Hall's exclusive 'marketplace'. ${ }^{20}$ 
A Penguin book might reach at most a few hundred thousand readers, many of whom were already participants in the period's Marxist renaissance. Historians interested in how millions of less obviously politically committed Britons were drawn into the battle of ideas need to look at television, for it was in the 1970 s when the medium 'came of age' and began to play a significant role in the national culture. ${ }^{21}$ By the start of the decade more than 90 per cent of households possessed a TV set and adults devoted on average 18 hours a week to watching it. ${ }^{22}$ Viewers had access to three channels, two of which were funded by a compulsory licence fee and run by the British Broadcasting Corporation (BBC) as a public service. The third was financed through advertising and operated by one of fifteen regional affiliates to Independent Television (ITV), regulated by the Independent Broadcasting Authority (IBA). ${ }^{23}$ Raymond Williams believed that, thanks to television by this decade, 'for the first time a majority of the population has regular and constant access to drama'. ${ }^{24}$ Britain possessed that which Dennis Potter called, 'the nearest thing we are ever likely to get to a "theatre of the people"'.25 Most working in this 'theatre' saw their object as the provision of ostensibly value-free drama. ${ }^{26}$ Nonetheless from the early 1960s TV was opened up to voices that challenged the existing order so as to reflect a society increasingly in conflict with itself. Censorship did not disappear, with those leading the BBC in particular wishing to protect the 'Westminster consensus' from criticism. ${ }^{27}$ Dramatists were nonetheless freer than ever before to explore onceforbidden ideas. As a result, the lives of working people were represented in unprecedentedly realistic terms, for the people themselves as they sat in their homes. ${ }^{28}$ 
Many of these dramas, most prominently the soap opera Coronation Street, (ITV, 1960- ) studiously avoided tackling controversial topics. ${ }^{29}$ Some, however, like the series Sam (ITV, 1973-5) focused on the past and present of the working class so as to comment on issues of the moment. A small number of plays and series even sought to encourage viewers to embrace socialism. They were, as the radical BBC drama producer Tony Garnett put it, 'an inspiration to action' being designed to contribute to the left's challenge to the post-war settlement. ${ }^{30}$ As a more conservative voice in the BBC complained, such dramas constituted 'a form of political persuasion by other means' ${ }^{31}$ This article focuses on the work of Jim Allen (1926-99) and Trevor Griffiths (b. 1935), the two leading socialist writers working in the medium at this time. ${ }^{32}$ Allen was a Trotskyist and Griffiths influenced by the New Left. Both had resigned from the Labour party during the 1960s due to their frustration with the parliamentary leadership's moderation; so they sympathised with those in the party who wished to transform the post-war settlement from the left. If Tony Benn used speeches they employed drama to make their case. Allen spoke of wanting his plays to 'ring a few bells and stir people up', hoping 'works canteens will be buzzing with discussion of the issues' as a result and 'galvanize' working-class viewers to reject social democracy. ${ }^{33}$ Griffiths saw writing for TV as 'a massively powerful way of intervening in society's life': it was the only way dramatists could address large numbers of working people. ${ }^{34}$

Contributions to the 1962 Pilkington Report on Broadcasting revealed that many in authority believed TV shaped viewers' thinking. ${ }^{35}$ Conservatives were especially worried by how the medium was starting to give radical ideas a platform, which was why Mary Whitehouse established the National Viewers' and Listeners' 
Association in $1965 .{ }^{36}$ The ideas contained in Allen and Griffiths' dramas were anathema to such figures and they publicly refuted them. During her first leader's speech to the 1975 Conservative conference Thatcher echoed Whitehouse's concerns by describing Allen's series Days of Hope as part of the left's attack on 'our national self-respect' ${ }^{37}$ But it wasn't just the right which felt threatened. Griffiths' 1976 series Bill Brand also goaded the centre-left Guardian to publish an editorial defending Parliament as the principal venue for progressive change. ${ }^{38}$

This article has two related objects. It poses a substantive question: were nascent neo-liberals and long-time social democrats right to be concerned about the influence of Allen and Griffiths? To answer that query however means addressing a knotty methodological issue: what can historians reasonably say about the impact of television on vernacular ideas? This is a matter of importance to all interested in the communication of political ideas during the post-war period but especially during the fraught 1970s. The article draws these concerns together by systematically analysing the ways through which TV press critics working for the Daily Mirror and Daily Express tried to influence reactions to the men's work. It shows how keenly journalists working in a little studied part of the newspaper industry encouraged millions of working-class readers to reject the dramatists' ideas. The article thereby highlights not only the extensive nature of the battle of ideas but also the weight of those forces opposed to the socialist alternative to the ailing post-war settlement.

\section{The ideational effect of TV drama}

The historiography of television is in its infancy: it was only in 2007 that Helen Wheatley declared TV could be considered a 'legitimate field of study'. ${ }^{39}$ Two years 
later however Paddy Scannell claimed that as television had been established for seven decades historians were equipped to assess the effects of the medium. They not only possessed the requisite perspective he argued but the opening of the archives meant historians possessed the material with which to conduct analysis. ${ }^{40}$ As Scannell's work on the interwar BBC had outlined how far its radio output shaped popular ideas it was no revelation he was optimistic that historians would establish TV, a more powerful medium, had significantly influenced post-war Britain. ${ }^{41}$

At least in regard to television's impact on ideas other historians nonetheless believe it had a modest effect. Joe Moran suggested the medium's importance 'stems from its slowly accrued habits and rituals, the way it mingles with our daily routines' ${ }^{42}$ David Kynaston similarly claimed television had but two effects on the young: 'it made them stay at home more, and made them go to bed later'. ${ }^{43}$ It is understandable why such historians hold this latter view. Most dedicated students of television history have avoided exploring the medium's ideological effects. It is a common complaint that they have been too preoccupied with 'messages rather than recipients' ${ }^{44}$ Their focus has been on the production of programmes, the institutional politics in which that occurred, and broadcasters' relations with government. ${ }^{45}$ Likewise, students of radical TV drama of the kind written by Allen and Griffiths have highlighted the production context that gave it shape, discussed its use of dramatic techniques or assessed how it represented certain subjects. ${ }^{46}$ If they refer to the impact of such work, as when Edward Brandt claimed Griffiths' Bill Brand was 'an unequalled example of television drama as a form of extended political dialogue', they do so with precious little justification. ${ }^{47}$ 
If suffering from a lop-sided emphasis this work has nonetheless advanced an understanding of why certain messages reached the screen more than others and how TV depicted a variety of social and political issues. But it has done little to aid an appreciation of the ways audiences responded to what they watched. The likeliest reason for this imbalance is that assessing the production of messages is more straightforward than reconstructing their reception. The paper trail for the former can be followed with comparative ease, especially in a bureaucracy as officious as the BBC: methodological issues are simpler to resolve and conclusions can be drawn in a less ambiguous manner. In contrast, as Stuart Hood, Controller of BBC Television during the 1960s admitted, even contemporary broadcasters lacked evidence reliable enough to judge how viewers reacted to their programmes. ${ }^{48}$ Subsequent social scientists and students of culture who have made it their business to assess the ideological impact of TV have moreover produced work that emphasizes its complex, contingent and indirect character. Audiences are not blank slates upon which the screen imposes its meaning but can in subtle and various ways be influenced by what they watch. ${ }^{49}$ It was for these reasons Janet Thumim wrote of 'the impossibility of knowing an historical audience', and claimed how viewers interpreted what they saw on the screen, 'can only ever be a matter of speculation'.$^{50}$

Despite these issues some historians have recently attempted to move beyond pure conjecture. Despite the many difficulties surrounding the attempt, those interested in how television tackled race and immigration have drawn concrete conclusions about the medium's ideational impact. ${ }^{51}$ Analysing a contrasting set of broadcasts they agree television had important effects. Gavin 
Schaffer concludes that by 'shaping' how they understood the issue of immigration TV's overall output 'helped to set parameters of acceptability' for indigenous viewers by confirming the alien status of Caribbean and Asian citizens. ${ }^{52}$ Christina Hodenburg suggests that in an era in which TV entertainment formed a "battleground in which boundaries were fought, levels of acceptability tested and raging controversies fought' the popular situation comedy series Till Death Us Do Part (BBC, 1965-75) encouraged its white audience to be more racially intolerant. ${ }^{53}$ Finally Rob Waters argues that as a 'central site for the imagination of community' coverage of the Black Power struggle in the United States radicalized black British viewers' understanding of themselves. ${ }^{54}$ In making their cases each historian confronted the same issue: the absence of wholly dependable and representative data. It is therefore worth rehearsing some of problems with which they struggled.

\section{Flawed sources}

BBC Audience Research Department surveys of viewers' reactions to the Corporation's programmes play an important role in Schaffer and Hodenburg's accounts. ${ }^{55}$ The Department's frequent reports were based on responses posted in from its long-established 2,000 strong panel of volunteers. ${ }^{56}$ They contain invaluable comments from people watching at home, just like every other member of the audience. Hood however claimed panelists were unrepresentative, and many of the comments contained in the reports do have a pronounced bourgeois tone. It is nonetheless hard to be precise about this bias as findings were rarely distinguished along class, gender or any other lines, adding a further limitation to their utility. The surveys were moreover conducted ex post facto. Panelists wrote up their opinions 
after seeing a broadcast, meaning reports cannot measure a programme's effect, as respondents were not assessed before watching it. ${ }^{57}$ Finally the reports were rarely longer than two sides of A4: such brevity means it is possible they say as much about the opinions of those responsible for compiling them as they do about the panelists.

All three historians used letters written by viewers to broadcasters. These usefully supplement BBC audience reports. ${ }^{58}$ Yet, while providing further evocative qualitative data, correspondence is an even more problematic basis upon which to generalize, unless it is to illustrate as Schaffer puts it the 'diverse and unpredictable' nature of public opinion. ${ }^{59}$ For when compared to the millions who watched TV only a tiny number corresponded with programme makers: for example, despite the controversy surrounding Allen's Days of Hope the BBC received just 131 letters. ${ }^{60}$ Broadcasters were consequently doubtful about their value: Hood even dismissed such missives as 'cries for help'.

Waters is the only historian to use memory to establish his case, specifically that of a small handful of activists and artists, who could recall their response to key television moments, like the Black Panther salute at the 1968 Olympics. ${ }^{61}$ Setting aside concerns about the small numbers involved and their atypicality, memory presents dangers for those seeking to determine the wider ideological effect of particular broadcasts. Testimony can vividly suggest how one programme changed a life. But converts have often erroneously emphasized the impact of different kinds of text to explain in tangible terms their transformation. ${ }^{62}$ Without a bigger and controlled sample, or extensive biographical research to verify how TV interacted with the varied influences to which all individuals are subject, it is hazardous to take 
respondents at their word, let alone to draw wider conclusions from their testimony. ${ }^{63}$

\section{The possibilities of the press}

Historians wanting to explore TV's ideational effects therefore face sharp evidential problems; those cited above have done well to extract meaning from their material. Those wishing to go further have a choice. They can emulate those who have put aside positivist criticisms of the similarly problematic Mass-Observation Archive. That means embracing the subjectivity of the BBC audience surveys, letters and oral testimony to explore highly personal reactions to TV. ${ }^{64}$ Such an approach will likely produce thickly descriptive, highly illuminating histories of individuals' engagements with the medium. But those who aspire to gain a broader understanding of TV's impact on popular idea might want to go in another direction, one that accommodates at least some of the concerns of positivism. That is the ambition here and why the article argues for a more systematic use of the press.

Newspapers figure prominently in all three accounts, in the form of readers' letters, editorials, features and criticism. They play an especially important role in Hodenberg's study, arguing as she does that the press influenced viewers' reactions to what they saw on the screen. ${ }^{65}$ In this she follows the consensus amongst newspaper historians that, as Adrian Bingham has it, the press, being 'right at the heart of British popular culture', 'helped to set the tone' of vernacular discourse. ${ }^{66}$ Indeed, Colin Hay even argues that the way newspapers reported the 1978-9 strike wave commonly known as the 'winter of discontent' directly encouraged the electorate to embrace Thatcher's alternative to the post-war settlement. ${ }^{67}$ Even so, 
Hodenburg does not mention in any particular way journalists whose job it was to review, criticize and in various other ways interpret TV for their readers. Yet, with the top eight national titles enjoying a combined sale in excess of 14 million per day during the 1970s, TV critics held a privileged cultural position. In response to its popularity every paper had expanded coverage of television, most employing at least two or three reviewers. ${ }^{68}$ Through their columns, often headed by a portrait, critics were personalities in their title's universe, millions of readers' daily interlocutor on the subject of television. Some were themselves TV celebrities: the Daily Mail's Peter Black was so well known Rediffusion used him in commercials to praise their sets. ${ }^{69}$

In spite of their importance, critics perform an inexact role in all three accounts. They are cited but with little sense of context: opinions are rarely linked to the title that employed them let alone to an appreciation of the number and type of readers for whom they wrote. ${ }^{70}$ Moreover, there is no exploration of the kind of relationship critics tried to build with readers: the 'press and public' or 'critics and viewers' are commonly presented as interchangeable. ${ }^{71}$ Finally, and most confusingly, these accounts frequently implicate critics in authorial assessments, using them to legitimize points the author wishes to make about a broadcast, thereby blurring the line between source and analysis. ${ }^{72}$

This lack of specificity is unfortunate because, especially on the most popular dailies, critics aspired to intervene in readers' conversations about TV. Thanks to Mass-Observation we know viewers of early 1950s television did not sit quietly observing the small screen: they spoke to each other. ${ }^{73}$ As the communications specialist David Morley established in the 1980s these dialogues helped audiences draw significance from what they saw. ${ }^{74}$ American evidence from the same decade 
suggests that such discussions played a vital part in determining that significance. ${ }^{75}$ Indeed, according to sociologists Laurie Taylor and Bob Mullan: 'television drama has only properly occurred, been thoroughly realized, when the plots and the moral messages they contain have been discussed and interpreted and re-dramatised in the company of friends or mere acquaintances' ${ }^{76}$

Some broadcasts even provoked debates across the nation: as Hodenburg points out, one third of BBC audience panelists said they often discussed Till Death Us Do Part while most of the remainder claimed they did so at least occasionally. ${ }^{77}$ Letters sent to the BBC confirm this proclivity, with one correspondent writing of the series Pennies From Heaven (BBC1, 1978): 'An “in-depth" discussion took place each Wednesday morning in a local office of 20 bods, only three of us "oldies". I think you might be surprised at the profundity of discussion. ${ }^{78}$ The Head of BBC Children's Programmes even told colleagues that Griffiths' play All Good Men (BBC1, 1974), 'started an argument among those watching with her which had gone on a long time' $^{79}$

The content of these millions of private dialogues is however lost. The sources upon which historians might have relied to recover such conversations present stony ground. It is rare for diarists to record discussions about TV, and those few that do are, like the actor Kenneth Williams, exotically idiosyncratic. ${ }^{80}$ Nor do autobiographies mention viewing in detail. Some recent memoirs devoted to 'growing up watching telly' say almost nothing about how broadcasts were discussed. ${ }^{81}$ In this bleak environment TV critics present the least-worst chance for historians to evoke the likely shape of such discussions. 


\section{The significance of the critic}

Historians of all stripes have generally ignored TV critics, especially those working for the popular press. ${ }^{82}$ Most simply disregard the influence of newspapers that sold millions of daily copies. ${ }^{83}$ But even newspaper historians have denigrated those parts of newspapers that focused on entertainment, seeing the expansion of this coverage during the 1970s at the expence of hard 'news' as a source of regret and a sign of the depoliticisation of the press. ${ }^{84}$ Described as 'a forgotten part of our television culture', it is therefore little wonder students of the media have only just started to rescue press TV critics from obscurity. ${ }^{85}$ Historians of 1970s TV drama are as guilty of this oversight as everybody else, with John Tulloch standing alone in recognizing their significance. Even so, being only interested in critics' aesthetic judgements Tulloch focused on those employed by the comparatively little-read elite press. ${ }^{86}$

Critics worked for a press which during the 1970s was, partly in response to the increasingly troubled post-war settlement, increasingly partisan. ${ }^{87}$ All journalists operated within their newspaper's persona, described by Stuart Hall as its 'core values ... which provide its staff and its readers with a coherent, if not consistent, scheme of interpretation' ${ }^{88}$ Critics used this persona to establish a rapport with readers something so deeply ingrained they rarely felt the need to make explicit. Unusually Sean Day-Lewis of the Daily Telegraph - a paper that supported the Conservative party and whose readership was largely bourgeois - did once refer to 'we of the despised middle classes' when reviewing Griffiths' Bill Brand, a series he correctly judged was not meant for them. ${ }^{89}$ Yet, when prompting readers to see TV in particular ways critics were not always the unquestioning slaves of an editorial line or their readers' presumed preferences. ${ }^{90}$ So as to retain rapport with readers, 
maintain their personal integrity and not antagonize their Editor, critics could walk a narrow line. The Daily Express' James Thomas for example clearly accepted the proposition illustrated in Allen's The Spongers (BBC1, 1978), that many on state benefits were badly treated by the authorities. But bearing in mind how keenly the Express supported the Conservatives and the divisive nature of Allen's argument, he tactfully concluded: 'I imagine his audience would not find much to sympathy with $i t^{\prime}{ }^{91}$ For the price of losing their readers' affinity and straying too far from their title's persona could be fatal. After being attacked by a correspondent for her 'bourgeois, maundering, subjectivism', Tribune's Audrey Williamson was quickly replaced by a more appropriate critic. $^{92}$

The BBC drama producer Irene Shubik claimed TV critics, 'purport to be representatives of the people: "Mr Joe Average" reacting' ${ }^{93}$ Those employed by popular titles tried to establish this persona by using the first person, colloquial language and humour, while referring to watching TV with their families, just like their readers. The Manchester Evening News' Stanley Reynolds even reported on discussions about TV he had in his local pub. ${ }^{94}$ Critics also mentioned letters from readers who disagreed with their views to suggest they were but the first amongst equals. Certainly, despite working for the up-market Observer Clive James confirmed Shubik's assertion when he asserted: 'Television is for everybody. It follows that a television critic, at his (sic) best, is everybody too. ${ }^{95}$

Aiming to be regarded as the Everyman, critics ingratiated themselves into conversations about TV. Seeing his writing as 'a necessary condiment to the watching of television', while working for the Daily Mail and Sunday Telegraph, Philip Purser aimed, 'to give enough account of the programme to catch the interest 
of those who hadn't seen it without boring those who had, and to register an opinion of it'. Significantly, Purser claimed his object was to 'pick up and continue whatever debate there had been round the set last night'. ${ }^{96}$ By employing these methods critics sought to act as opinion leaders within what in another context sociologist Janice Radway referred to as 'interpretative communities', which in their case could consist of millions. ${ }^{97}$

TABLE 1 HERE

To reconstruct how critics tried to affect readers' discussions about Allen and Griffiths' work, analysis principally focuses on their series Days of Hope and Bill Brand. Broadcast over a protracted period weekly series gave critics time to reflect and allowed viewers the opportunity to discuss them. As Purser recalled of an installment in this genre: 'People talked about it or thought about it between episodes, building up anticipation for what was to come. The audience did half the work. $^{98}$

Being the two most popular papers of the period, focus falls on how critics working for the Daily Mirror and Daily Express framed these series. ${ }^{99}$ Each had well established and distinct personae, neither of which cared for socialism. The Mirror, with an average daily circulation in 1975 of 3.9 million was the country's best-selling paper. It was also unique on Fleet Street in supporting the Labour party, usually taking the side of the party's social democratic leaders against their left-wing critics. The paper had a 'patriotic' populist rather than class-conscious persona, and so invariably attacked demonstrators and strikers it described as 'screaming 
militants' ${ }^{100}$ In contrast, the Express enjoyed a circulation of 2.8 million and was a redoubtable Conservative partisan, one wholly antipathetic to 'class warfare'. If politically distinct, the papers had similar social constituencies although 85 per cent of Mirror readers came from the manual working class compared to the 60 per cent found reading the Express. As a result, both sets of critics addressed a largely proletarian audience, of the sort Allen and Griffiths wished to reach.

What is referred to as 'soft criticism', that is stories related to TV but focusing on leading actors or the clothes they wore is also included within the analysis. ${ }^{101}$ The Mirror and Express enthusiastically indulged in this kind of coverage but it was something in which the listings magazines Radio Times and TV Times specialized. In 1975 the former had a circulation of 3.5 million - it was Britain's most read weekly and at 3.3 million the latter was close behind. Respectively affiliated to the BBC and ITV, their main purpose was to find ways of inducing readers to watch their patron's broadcasts. In that capacity they prompted audiences in how they should respond to Allen and Griffiths' dramas. ${ }^{102}$

\section{Socialist dramatists}

During the 1970s Britain's most popular TV fare consisted of the Miss World final, situation comedies, soap operas, Hollywood movies and light entertainment. ${ }^{103}$ This period is nonetheless now regarded as the 'golden age' of broadcasting because drama producers were relatively free of the traditional necessity to pander to the powerful and of what would later become tight commercial constraints. ${ }^{104}$ TV bureaucracies at this time were pretty informal: commissioning often occurred very quickly. Griffiths won the chance to write the pilot for Bill Brand over dinner with 
just one Thames Television executive. ${ }^{105}$ Tony Garnett often eluded scrutiny from lax or easily duped BBC managers, which allowed him to produce Allen's dramas almost uncensored. ${ }^{106}$

This relative autonomy was nonetheless mainly confined to sharply delineated parts of the schedule, most notably The Wednesday Play/Play for Today series (BBC1, 1964-70/1970-84). ${ }^{107}$ As the BBC Head of Current affairs said in relation to complaints that Allen's Big Flame constituted socialist propaganda, it was 'not wrong to broadcast an occasional view that was entirely against the status quo in society in view of the fact that the implications of so much of the output were in its favour. ${ }^{108}$ Indeed, a 1975 BBC survey estimated that during the previous two years the Corporation had broadcast just a dozen 'political plays' ${ }^{109}$ This still meant radical writers enjoyed a historically unprecedented chance to speak directly to millions and the possibility to, as the dramatist David Edgar put it, 'inject socialist content into mass populist forms'. ${ }^{110}$ This was a limited opportunity about which Allen and Griffiths were not naïve. The former wrote The Talking Head (ITV, 1968), which explored the dilemmas of being a socialist and making TV drama. His scripts usually contained pointed references to how far television distorted reality for the benefit of the powerful. Griffiths' work similarly highlighted the extent to which TV reinforced the status quo. He certainly appreciated how far television was the place where, 'people want fantasy. They don't want their own lives exposed. It's the way we have been shaped by years of the careless medium' ${ }^{111}$

Both used realism rather than experimental forms to ensure they spoke to the TV audience in familiar terms. ${ }^{112}$ Other socialist dramatists and critics censured them for that: they believed realism prevented audiences asking critical questions as 
it diminished the possibilities of demonstrating contradiction. ${ }^{113}$ But when socialist drama abandoned realism, as in David Hare and Howard Brenton's Brassneck (BBC1, 1975), the results were not positive. Their play, about how a building contractor becomes rich through corrupting politicians of all parties, attacked the shortcomings of the post-war settlement as fervently as Allen and Griffiths but its experimental Brechtian techniques left $B B C$ panelists confused and it was one of the worst received dramas in the history of Play for Today. ${ }^{114}$

Like most other socialist writers Allen and Griffiths' work was mostly restricted to single plays broadcast in The Wednesday Play/Play for Today slot. However, unlike their peers, they also each wrote a series: Allen penned the fourpart Days of Hope and Griffiths, the eleven-episode long Bill Brand. The former was broadcast in the Play for Today slot of $9.25 \mathrm{pm}$ on Thursdays but Griffiths ensured his series ran at $9.00 \mathrm{pm}$ on Mondays on ITV, an exceptional time for challenging drama on the commercial channel. He prevailed over schedulers who wanted to place the series after News at Ten, arguing: 'my class, the people I want to talk to, don't watch from 10.30 p.m.' ${ }^{115}$ Brand was nonetheless broadcast during the summer when viewing figures were at their lowest.

Usually working with director Ken Loach and always with producer Tony Garnett, Allen's plays relied on the techniques the pair made famous in Cathy Come Home (BBC1, 1967). To enhance realism they employed non-actors, outside locations and a way of shooting film then current in television news. ${ }^{116}$ Reflecting his Trotskyite background Allen's scripts depicted trade union bureaucrats and social democratic Labour politicians as complicit with capitalism so they always betrayed those they were meant to represent. His dramas were nonetheless optimistic 
inasmuch as they suggested that freed from these leaders and the illusions of parliamentarianism workers had the innate capacity to build a socialist society. Allen's perspective was one with which Tony Benn had much sympathy.

To illustrate his case, in The Big Flame (BBC1, 1969) Allen has a dock strike turn into workers' control of the port of Liverpool. The army intervenes and while the dispute's leaders are imprisoned they remain defiant, taking defeat as a strategic victory. Rank and File (BBC1, 1971) dramatized a real strike that broke out amongst once quiescent St. Helens glassworkers the year before: it showed labour movement representatives to be their enemy as much as their employers. Also mixing real and fictional events, Days of Hope surveyed British history from the Great War to the General Strike, culminating in what Allen presented as the Trades Union Congress and Labour establishment's betrayal of striking miners. If set in the past, Allen declared, 'The message is: don't let it happen again'.117 He returned to a contemporary setting with The Spongers (BBC1, 1978), which traced the impact of a Labour council's cuts to social services in line with edicts issued by the Callaghan government. Allen focused on how these harmed Pauline, a beleaguered single parent living on a council estate. Culminating in her suicide this was seemingly a play without hope although it ends with one of Pauline's neighbours defiantly stating: 'she should have stayed and fought like the rest of us'.

Griffiths' largely studio bound work was more opaque exploring as it did the dilemmas faced by socialists in a democracy. ${ }^{118}$ If Allen's work was dramatised Trotsky, Griffiths used Ralph Miliband's Parliamentary Socialism (1961) a text then popular with the Labour left as the basis for his analysis. Certainly, his first television effort, All Good Men (BBC1 1974), took up a key Milibandian theme by suggesting 
the Labour protagonist was so committed to the parliamentary road he had abandoned the working class. In the same year Griffiths wrote 'Absolute Beginners', broadcast as part of the BBC1 period drama series Fall of Eagles. This critiqued Lenin's imposition on the Bolsheviks of his brutal notion of the centralized party. Thematically similar, Occupations (ITV, 1974) explored the Turin events of 1920 and showed a brusque Comintern agent pursuing Leninist realpolitik.

Bill Brand in contrast explored the problems of the contemporary British left and many of the issues faced by the current Labour government. Brand was a newly elected MP, a former student militant who, like many of his real counterparts such a Ken Livingstone, joined Labour despite misgivings about its moderation. He enters the Commons with his government responding to an economic crisis by cutting welfare. Brand becomes involved in a leadership election and for a time it looks like MPs might elect a socialist. But instead they choose another social democrat who continues policies that hurt the working class so as to preserve the post-war settlement. Oftentimes Brand cuts an impotent figure but despite this, the series ends with him hopeful socialism might still happen. For his hitherto apolitical working-class brother has been radicalized after participating in a Right to Work demonstration.

Reflecting his pluralist politics, Griffiths' dramas were sometimes so subtle, it wasn't always clear for whom viewers should be rooting. The arguments he has his social democrats and socialists advance were finely balanced while his heroes, most obviously Brand, were intellectuals wracked by uncertainty over how to mobilize the proletariat. In contrast, Allen's work was, like his version of socialism, visceral, less 
dilatory and had working people as their protagonists. If Griffiths posed agonized questions, Allen gave unambiguous answers.

Their dramatic and political approaches were distinct, but Allen and Griffiths each gave women roles more significant than other, almost exclusively male, socialist TV writers. ${ }^{119}$ Even so, the workplace setting of The Big Flame and The Rank and File relegated women to a domestic sphere Allen presents as impeding the class struggle. But in Days of Hope, Sarah Hargreaves has a crucial part as Allen's mouthpiece and while The Spongers cast Pauline as victim her female neighbours are more robust. All of Griffiths' principal protagonists were men, but women played noteworthy if subsidiary roles, most especially the radical feminist Alex Ferguson, Brand's most articulate political critic.

\section{The audience for socialist drama}

The Joint Industry Committee for Television Advertising Research (JICTAR) published weekly lists of Britain's twenty most popular programmes and one for the ten most watched in ITV's fifteen regions. Neither Allen nor Griffiths featured in any of them. BBC figures however suggest that between 6.5 per cent and nearly 21 per cent of the population watched their dramas. This data does not reveal viewers' demography but in dealing with the male-dominated world of politics and industrial conflict, it is likely their work disproportionately appealed to men. As The Spongers attracted the most viewers and exceptionally focused on a female protagonist in a domestic setting, it is arguable that had Allen and Griffiths included more important women characters in female-friendly contexts - as did soap operas - their work might have attracted bigger audiences. ${ }^{120}$ Significantly Griffiths' most popular play during this 
period, Through the Night (BBC1, 1975), had an archetypal female theme: it was about a woman with breast cancer. Eleven million viewers watched and it sparked an extensive debate in the press about how the medical profession should treat women facing a mastectomy. This was a 'political' play insofar as it dealt with the power male doctors exerted over female patients, but few contemporaries recognized it as such. ${ }^{121}$

A relatively low audience share was usual for all single plays: being one-offs, they did not benefit from the familiarity crucial to popularity. The performance of Days of Hope is therefore worth highlighting. The series had the potential to build an audience through holding a fixed place in the schedule. Yet, after its first episode, Days of Hope lost over a quarter of its viewers. This was partly due to being scheduled against The Morecambe and Wise Show, a well-liked light entertainment series, which started on BBC2 in its second week. Whatever the reason, with ITV's adaptation of A.J. Cronin's novel The Stars Look Down already established on Thursday nights at 9.00, Days of Hope condemned BBC1 to the rare fate of being the least watched of the nation's three networks.

\section{TABLE 2 HERE}

As an ITV series, establishing the audience for Bill Brand is trickier but it can be estimated thanks to JICTAR. ${ }^{122}$ For the benefit of advertisers JICTAR established panels throughout ITV's regions. But rather than providing an average of the number of viewers for a programme, like the BBC, JICTAR calculated how many households watched on a minute-by-minute basis. This allowed advertisers to know where best 
to place commercials but it also gives historians a microscopic insight into viewer preferences. For the purposes of illustration, Brand's performance in the Tyne Tees franchise has been selected, covering as it did the North East of England. With 75 per cent of the nearly 1,000 households forming the JICTAR panel designated as social class C2, D or E, this was ITV's most proletarian region.

Brand faced competition from the 9 O'clock News on BBC1 and, after 9.25, a feature film or sports broadcast; at the same time BBC2 repeated The Pallisers, a poorly received serial adaptation of Anthony Trollope's political novels. Against this inauspicious competition it was still exceptional for Brand to attract a plurality of viewers, indeed that only occurred in its sixth week when BBC1 broadcast The Royal Horse Show. This was also one of the few weeks in which an episode gained viewers between the start and end of its transmission. When BBC1 ran a western or gangster movie however Brand lost a significant number of its audience. Like Days of Hope the series failed to build audience loyalty. From attracting 25 per cent of households at the start of its opening episode, Brand hit a peak of 30 per cent (against BBC1's horses) in week six; but by the end of its final episode only 15 per cent were still watching. Due to the manner in which JICTAR presented its data it is hard to precisely calculate Brand's weekly average audience, but it was close to 20 per cent of North East homes.

Compared to the likes of Miss World, the audience for socialist drama was small, the absolute size for work that hitherto would have been mostly confined to non-commercial theatres, was greater than it had ever been. Poor though it was, had Brand's performance in the North East been reproduced across Britain it would have attracted an average of eight million viewers every week. ${ }^{123}$ Similarly, if never 
amongst the BBC's most popular fare, audiences for Allen and Griffiths' work ranged from three to nearly nine million. ${ }^{124}$ But how did those who watched receive these dramas? Given its reputation for dealing with controversial issues, audiences for the Wednesday Play/Play for Today slot were likely to have been the most appreciative of socialist drama. Yet, with only three channels from which to choose, even that strand attracted viewers for unlikely reasons: 22 per cent watched Days of Hope simply to pass the time while 32 per cent said it allowed them escape the pressures of life, an odd motive given its gritty subject matter. ${ }^{125}$

Of those who watched All Good Men, the BBC survey claimed, 'it seemed that political themes were not welcomed by a good many ... in whose opinion they never make good entertainment, and tend to be particularly boring and depressing at the present time.' Comments cited indicate some found Griffiths' play heavy going, comparing it to an election broadcast and so, as one panelist claimed, not something they wanted to see 'after a day's work'. ${ }^{126}$ The report on The Big Flame suggested the audience was more equally divided. On the one hand were those who considered, 'the present diet of head-line-hitting news about labour troubles was wearisome enough without a serving of plays on TV'; on the other some appreciated the insights Allen gave them into industrial conflict. ${ }^{127}$ Perhaps due to its domestic setting The Spongers report made no reference to criticism of its 'political' nature, instead claiming all but a few found it a 'highly thought-provoking experience'. ${ }^{128}$ Such variation could be due to the dramatic success or failure of the individual plays and how panelists' comments were edited. But, if the exact proportion varied, it is clear that not everyone who watched socialist drama appreciated the experience. 
The popular press encouraged this aversion. The elite Financial Times critic praised Griffiths' Occupations, and called for more plays 'of an uncompromisingly political nature', but colleagues with mass circulations did the opposite. ${ }^{129}$ The Mirror's TV coverage made it plain the paper believed the medium existed to provide readers with value-free amusement. Indeed as the newspaper historian A.C.H. Smith suggested, the Mirror's heroes included 'entertainers, the fun-makers of television' as they accorded with its persona. ${ }^{130}$ Whatever was broadcast, the Mirror did its best to present TV in 'showbiz' terms. Photographs of attractive young female actors appearing in the production often partnered references to even the most heavyweight drama. Tellingly, the only time the Mirror used a picture to accompany listings information for Brand it showed the MP (in the series very reluctantly) judging a beauty contest. ${ }^{131}$

\section{Bill Brand}

The Mirror was not alone in framing socialist drama in frivolous terms. In trying to drum up an audience, TV Times avoided as best it could Brand's political content. Instead the weekly highlighted its protagonist's personal 'integrity' and 'idealism' and stressed his soap-opera-style 'complicated private life'. To further reinforce the impression the series was a conventional drama, TV Times even ran stories about its 'stars', describing Jack Shepherd as a 'cerebral sexpot' and revealing the 'strikingly attractive' Lynne Fairleigh loved cats. ${ }^{132}$

To an extent this framing was a consequence of Griffiths' embrace of conventions common to popular TV drama, ones he used to establish a connection with viewers. This meant the series tackled Brand's failing marriage and affair with a 
younger woman played by Cheri Lunghi. Indeed to further leaven matters Brand and his lover, a Womens' Studies lecturer, debate politics in bed, something that led to occasional nudity. These naked discussions troubled critics in the socialist press: the Communist Morning Star disapproved of this 'touch of popular titillation' while the left-Labour Tribune saw it as evidence Griffiths looked on women as 'sex objects'. ${ }^{133}$ In contrast, Tony Pratt of the Mirror approved, considering on more than one occasion, the 'remarkably pretty' Lunghi provided the only moments of relief in what he considered an otherwise dreary drama. ${ }^{134}$

For Pratt Brand's populism failed to sugar the pill of its otherwise challenging content. Wanting the series to raise critical questions in viewers' minds, Griffiths' dialogue did not simplify; as he said, those 'who don't know the political jargon will have to pick it up as they go along' ${ }^{\prime 135}$ The basic issue with Brand, as with Griffiths' work in general was however one of perspective. The series focused on how socialists should engage with the working class, not on how working people - and so most viewers - might relate to socialism. Notably, Brand's unemployed brother starts the series politically disengaged, like many in the ITV audience. But the series presents him - and so them - as one of the problems the MP must negotiate on the road to socialism. This standpoint was probably why Brand was so popular with Labour MPs and prominent members of the International Marxist Group: it dealt with politics from their standpoint. ${ }^{136}$ These were however not the people Griffiths wanted to reach. The reaction of the Tyne Tees audience suggests working-class audiences were less impressed. A TV Times correspondent, who claimed to be a young working-class father, even sarcastically looked on Brand as '[y]et another 
trendy, young, ex-working-class lefty'. ${ }^{137}$ It is a comment that betrays disaffection with Griffiths' protagonist amongst those to whom he wished to appeal.

In reacting to socialist drama, Mirror critics behaved as if raising political issues on TV was an abuse of a medium. But some went further to imply the subjects it tackled - in fact 'politics' as a whole - were an alien imposition on readers' lives dedicated to the pursuit of pleasure. This was especially the case with Mary Malone, one of the few female critics of the time, who for years had led the charge against what she punningly referred to as 'the Wednesday Plagues' ${ }^{138}$ Of The Big Flame, she claimed most would turn to another channel if they were anything like her - and she always strove to establish they were - as 'mention the Devlin Report to me, natter about clauses and amendments and I go sick and glassy-eyed' ${ }^{139}$

When Brand began its run, Malone looked on the MP as just one of those many parliamentarians, 'who are so busy wrestling with inner torments it's a wonder they have the time to get through all those bills telling us what to do'. ${ }^{140}$ She was not alone. A male colleague praised the series for giving viewers 'an accurate glimpse into the corridors of power', but still emphasized its 'dullness'. ${ }^{141}$ So far as Malone was concerned, Griffiths' series failed to connect with 'us'. Writing on the day its final episode was broadcast, she inveighed: 'A big weight is lifted from our viewing shoulders'. 'For the last time', Malone continued, 'you can feel your spirits sink as Trevor Griffiths's tutorial on political in-fighting resumes', describing it as presenting a 'picture of Westminster as a game only politicians can play. They are the actors and their own audience' ${ }^{142}$

There were issues with Griffiths' perspective that might have alienated working-class viewers. But Malone and colleagues chose to further estrange Mirror 
readers from the series and discourage them from reflecting on their subordinate place within Westminster politics, one of the key themes it explored. Instead, and in line with their papers persona, they presented Brand as actually confirming their readers' disaffection, not just from the socialism Griffiths hoped to advance but from 'boring' politics as a whole. It was perhaps no wonder so many preferred to watch Westerns.

\section{Days of Hope}

Due to the implacable nature his work, Allen provoked greater controversy than Griffiths. As BBC audience reports suggest, his dramas divided viewers. One said of Days of Hope, it 'brought tears to my eyes, hate for the army and pity for the people' and another claimed it 'left me feeling angry and frustrated'. Others however were left irate by Allen's 'blatant propaganda' and 'persistent bias against parliamentary government'. ${ }^{143}$

As middle-class professionals, critics were aware that in Allen's Manichean world they existed on the dark side. Writing for predominantly bourgeois readers, the Sunday Telegraph's Purser admitted The Rank and File initially made him sympathize with the workers' individual plights. But once they went on strike and 'coalesced together, jeering and shouting slogans and drumming up solidarity ... I began to grow restive with a line drawn so absolutely between right and wrong' ${ }^{\prime 144}$ It was to be expected that James Thomas of the Express would dismiss The Big Flame as 'a blatant piece of propaganda for Communism' ${ }^{145}$ But its relentless nature also provoked the Mirror's Malone to attack its case for workers' control of industry. Temporarily abandoning her congenial apolitical persona, she lectured the paper's 
overwhelmingly working-class readers that bosses were a fact of life. Claiming Russia was the only country that had ever abolished them, Malone concluded, 'and look at the trouble they have been going through since $1917^{\prime} .{ }^{146}$

Malone was also at pains to ensure Mirror readers appreciated The Big Flame was not reality. The class-conscious character of Allen's dramas meant they would have been attacked whatever method was used, but Loach's realist techniques added to their contentious nature. The Big Flame was twice postponed because BBC executives claimed it looked too much like the news and might mislead the audience. ${ }^{147}$ If viewers did not confuse Allen's fiction with fact, the form of their presentation certainly gave his message greater weight. Of The Big Flame one BBC panelist commented: 'we could almost smell the odours of mixed cargoes unloading, the garbage of the Liverpool dockland and the squalor of the workers' environment. Helped us sympathize with the struggling individuals'. ${ }^{148}$

Of all Allen's dramas, Days of Hope generated the greatest storm, the broadcasting of which, a Daily Telegraph editorial claimed, proved a 'Left-wing consensus' prevailed at the BBC. ${ }^{149}$ Edited by the former Conservative minister Bill Deedes, the Telegraph vigorously attacked the series, with its critic Richard Last describing it as: 'an unashamed party political broadcast for the Communist party the most prolonged commercial the comrades have enjoyed since the media were invented'. ${ }^{150}$ Allen having urged viewers to draw lessons about the present from the history he depicted, detractors exploited its most minor mistakes - such as how soldiers marched and their length of hair - to undermine his message. ${ }^{151}$ As that which Garnett called 'a statement on behalf of organized working people', it was no 
coincidence the only critics to think Days of Hope an accurate rendition of the past worked for Tribune and the Morning Star. ${ }^{152}$

Staying true to their general approach, the Mirror's critics avoided discussing the series as a political text. Instead they judged it as an entertainment, and found it wanting. Ken Irwin wrote of the first episode: 'There is plenty of atmosphere, hundreds of "extras" and some very poignant scenes', summing it up as: 'Terrific. But too long'. ${ }^{153}$ His colleague Kenneth Hughes noted the 'great deal of fuss' others in the media had made about its 'Left-wing leanings'. His view was nonetheless limited to the ostensibly dramatic - but clearly political - judgment that it was 'flawed by pointing up too sharply the goodness of the goodies and the ridiculing of the upperclass establishment baddies.' ${ }^{154}$

Reflecting their paper's distinct persona critics working on the Daily Express reacted differently. They did not necessarily have a principled opposition to socialist drama that mixed fact with fiction. The year before Days of Hope was broadcast James Thomas had welcomed Griffiths' Occupations, as 'a record of a slice of history'. ${ }^{155}$ But as a one-off play, set in Italy five decades in the past, and shown late on Bank Holiday Sunday evening Occupations had no chance of attracting a mass audience. Days of Hope in contrast asked pressing questions about contemporary Britain, at prime time and for four weeks. So, Express critics set about systematically highlighting what they claimed were its biases. Even summaries on the paper's normally purely descriptive TV listing pages told readers of its 'less than accurate history'. In this way they were repeatedly informed that the series represented Allen's biased views wrapped up in an 'apparently documentary form', so they should not confuse it with the actual past. ${ }^{156}$ 
At the series' conclusion, James Murray even gave readers an alternative historical interpretation of the events depicted in what he called 'the Left-wingers' favourite show'. According to him, Prime Minister Stanley Baldwin was 'a cool Tory pragmatist' who outwitted union leaders unwilling to lead their members into 'anarchy'. The General Strike ended, Murray argued, because after nine days 'Britain had tasted enough of revolution'. If Allen 'saw a restoration of order as a betrayal of the working classes by their leaders and their rulers', he went on, '[t]he piece had another lesson, though. Argue and squabble we may, but the British gift for common sense overcomes fevered tribulation. The hot-heads may bay for blood, but hot air does not make revolution. ${ }^{157}$ So far as Express readers were concerned, therefore, Days of Hope was the occasion for their instruction in a traditionally patriotic view of history, a version of the past - and so of the present - that completely refuted the one advanced by Allen.

After its first episode Murray claimed he doubted viewers would draw the conclusions the makers of 'one of the most impressive-looking political series we've seen on television' hoped they might. ${ }^{158} \mathrm{He}$ and his colleagues certainly tried to ensure that was true of Express readers, but the Radio Times performed a similar function for its audience. As was usual at the start of any major series, Allen, Loach and Garnett were interviewed to publicise Days of Hope. During this they claimed the ending of the General Strike was a betrayal that prefigured the treachery of 1970s Labour leaders. But, in an unprecedented step, in the ensuing article journalist Neil Lydon attacked the series. He claimed that as history it was spurious while its politics meant the series was dramatically weak, stating, 'it tries to make flesh of an idea - or, rather, of a series of political ideas held in conflict with each other by the 
leading characters'. Such 'dramatised political disputes' he maintained 'lack[ed] the edge of reality'. ${ }^{159}$ Even before it had begun, Radio Times readers were therefore told by the BBC's own in-house publication to regard Days of Hope skeptically.

\section{Conclusion}

Looking back on this period Jim Allen's producer Tony Garnett recalled: 'Those were days of such revolutionary optimism that I thought we could make one film and change the world.'160 Neither Allen nor Trevor Griffiths were ever so sanguine. But they did hope that writing for television would contribute to their viewers' radicalization, something Margaret Thatcher, for one, feared might happen.

Other socialist dramatists believed TV was the wrong medium for those seeking to win audiences over to radical ideas. David Edgar believed the theatre was the only venue for that, arguing most people watched television in, 'the atomized, acollective arena of the family living room' where they were 'at their most conservative and reactionary'. ${ }^{161}$ Edgar was right inasmuch as television was generally watched at home in small groups. But as various social scientists have indicated that was just the start of the discursive process through which ideas achieved their full meaning. For, as the critic Stanley Reynolds, remarked in 1976: 'The best TV is always what everyone is talking about the next day.' ${ }^{162}$ Weekly series, such as Bill Brand and Days of Hope, were especially likely to generate debate. Indeed, one reason for watching the latter, offered by nearly half of those surveyed by the $\mathrm{BBC}$, was that it gave them something about which to talk with friends. ${ }^{163}$ According to the Daily Mail critic Shaun Usher, writing halfway through its run, Days 
of Hope, undeniably supplied its audience with something to discuss as it is doing the apparently impossible - making ordinary folk think and argue about politics' ${ }^{164}$

As their main function was to ingratiate themselves into discussions about TV, the columns of newspaper critics give historians their least-worst chance of establishing the possible shape of these arguments, and so the ultimate effect of Allen's and Griffiths' work. As with all forms of cultural history - including of course television - there is no absolutely definitive evidence as to how those who wrote for the press influenced their readers. ${ }^{165}$ Adrian Bingham suggests the press 'reflected and shaped' attitudes but concedes it lacked the ability to coerce readers into accepting its point of view. ${ }^{166}$ Operating with different methods, social scientists have however established that the press can affect how people think about a variety of subjects. ${ }^{167}$ They have also produced evidence that press criticism in particular can influence audiences' understanding of TV drama. ${ }^{168}$ There are then grounds for believing that the critics highlighted here held some way over their readers. Given the nature of the subject and of the sources, reference to critics cannot however be a panacea for historians struggling to define the ideological impact of TV. But by assessing their output in a systematic manner they can establish, case by case, the bounds of speculation, to at least better define the likely parameters of those millions of discussions in which reviewers wished to participate. To be blunt, historians have two choices: make the best use of the imperfect material they have to hand or abandon themselves to pure conjecture.

We should not be surprised the critics discussed here encouraged readers to reject the implications of socialist drama. Stuart Hall saw the 'ventriloquists of populist opinion' in the press as crafting ideas amenable to the radical right. ${ }^{169}$ In 
particular, Colin Hay suggests that during the 'winter of discontent' the Express and Mirror helped concoct a spurious narrative in which Britons were held hostage by the trade unions. It was a story that made Thatcher's attack on the post-war settlement more plausible and so significantly improved her chances of election. ${ }^{170}$ But this role was anticipated some years before when Britain appeared threatened by dramatised versions of the same militant labour movement. This more insidious and everyday ideological battle was fought not on the front pages of the nation's press but inside, in the columns of their television critics; nor was it conducted just for the few weeks during the winter of 1978-9 but over many years. As this article confirms, these entertainment pages, which post-war surveys show always attracted most readers' attention, could be just as political as those dedicated to Westminster. ${ }^{171}$

On their own a few TV plays promoting socialist ideas were never going to revolutionise Britain's ideological landscape nor did the implacable rejection of these ideas by press TV critics make Thatcher's 1979 election inevitable. What they reveal however is evidence that a battle of ideas was being fought in what even today some political historians might consider the unlikeliest parts of the national culture. Well beyond Peter Hall's rarefied 'marketplace for ideas' ordinary Britons were debating the nature of their governance as the post-war settlement cracked. Allen and Griffiths took their chance to influence vernacular political ideas on a mass scale, to restock the cultural "tool kit" of which Anne Swidler referred. But against them stood those who wished to redirect their millions of readers in a different direction. Such a debate played no direct part in the shift from the state to the market in public policy engineered by the Thatcher governments of the 1980s. But it reveals some of 
the grounds on which she pitched her appeal in May 1979 when as Stuart Hall put it the Conservative leader translated for the sake of the electorate, 'economic doctrine into the language of experience, moral imperative and common sense' ${ }^{172}$ 
Table 1: Percentage of Readers of selected Newspapers and Listing Magazines by Gender and Social Class in 1975

\begin{tabular}{|c|c|c|c|c|c|c|c|c|}
\hline & Male & Female & A & B & C1 & C2 & D & $E$ \\
\hline $\begin{array}{l}\text { Daily } \\
\text { Express }\end{array}$ & 54 & 46 & 2.7 & 11.8 & 28.7 & 30.8 & 17.9 & 12.4 \\
\hline $\begin{array}{l}\text { Daily } \\
\text { Mirror }\end{array}$ & 55 & 45 & 0.5 & 3.9 & 18.8 & 41.5 & 28 & 16.4 \\
\hline $\begin{array}{l}\text { Radio } \\
\text { Times }\end{array}$ & 46 & 54 & 4 & 16.2 & 28.7 & 27.3 & 16.5 & 16.7 \\
\hline TV Times & 46 & 54 & 2.1 & 10.9 & 25.6 & 32.2 & 21.2 & 15.4 \\
\hline
\end{tabular}

Source: National Readership Survey. 
Table 2: The TV Audience for Work by Jim Allen and Trevor Griffiths

\begin{tabular}{|c|c|c|}
\hline Year of first broadcast & Allen & Griffiths \\
\hline 1969 & $\begin{array}{l}\text { The Big Flame (BBC1) } \\
13.6 \%(5.75 \mathrm{~m})\end{array}$ & \\
\hline \multicolumn{3}{|l|}{1970} \\
\hline 1971 & $\begin{array}{l}\text { Rank and File (BBC1) } \\
6.9 \%(3 \mathrm{~m})\end{array}$ & \\
\hline \multicolumn{3}{|l|}{1972} \\
\hline \multicolumn{3}{|l|}{1973} \\
\hline 1974 & & $\begin{array}{l}\text { All Good Men (BBC1) } \\
9 \%(3.75 \mathrm{~m}) \\
\text { Occupations (ITV) } \\
\text { N/A } \\
\text { Absolute Beginners (BBC1) } \\
\% \text { N/A (but } 4.5 \mathrm{~m})\end{array}$ \\
\hline 1975 & $\begin{array}{l}\text { Days of Hope }(B B C 1), \\
4 \text { parts } \\
\text { 1: } 9.5 \%(4 \mathrm{~m}) \\
2: \text { N/A } \\
\text { 3: } 6.5 \%(2.75 \mathrm{~m}) \\
4: 7.1 \%(3 \mathrm{~m})\end{array}$ & \\
\hline 1976 & & $\begin{array}{l}\text { Bill Brand (ITV), } \\
11 \text { parts } \\
\text { Average: } 20 \%(8.25 \mathrm{~m})\end{array}$ \\
\hline \multicolumn{3}{|l|}{1977} \\
\hline 1978 & $\begin{array}{l}\text { The Spongers (BBC1) } \\
20.7 \%(8.75 \mathrm{~m})\end{array}$ & \\
\hline
\end{tabular}

Source: BBC Audience Research Department reports; JICTAR, Weekly TV Audience

Reports; and Social Trends 39 (HMSO, 2009), p. 14. 


\section{Notes}

${ }^{1}$ For an insightful analysis of the 'ideational turn', Dean Blackburn, 'Still the stranger at the feast? Ideology and the study of twentieth century British politics', Journal of Political Ideologies_22:2 (2017), pp. 116-130. See also Jeremy Nuttall, 'Ideology in action' in David Brown, Robert Crowcroft and Gordon Pentland (eds), The Oxford Handbook of Modern British Political History, 1800-2000 (Oxford, 2018).

${ }^{2}$ The basic character of the settlement is outlined by P. Addison, The Road to 1945 (1975; 1994 ed.), pp. 279-92 and R. McKibbin, Classes and Cultures. England 19181951 (1998), pp. 528-36.

${ }^{3}$ Most notably, Addison, Road, p. 281; Richard Toye, 'From "Consensus" to "Common Ground": the rhetoric of the postwar settlement and its collapse, Journal of Contemporary History, 48:1 (2012), p. 7 and 23; and Kevin Hickson, 'The Post-War Consensus Debate Revisited', Political Quarterly, 75:2 (2004), pp. 150-3.

${ }^{4} \mathrm{Jim}$ Tomlinson, The Politics of Economic Decline (2014), pp. 83-99.

${ }^{5}$ For the United States, see Daniel T. Rodgers, Age of Fracture (Harvard University Press, 2011).

${ }^{6}$ For example: Ben Jackson, 'At the Origins of Neo-Liberalism: The Free Economy and the Strong State, 1930-1947', Historical Journal, 53:1 (2010), pp 129-151; Ben Jackson and Robert Saunders (eds), Making Thatcher's Britain (Cambridge, 2012), Part 1; Charles Moore, Margaret Thatcher volume one (2013).

${ }^{7}$ The Urtext for this approach is Peter A. Hall, 'Policy Paradigms, Social Learning, and the State: The Case of Economic Policymaking in Britain', Comparative Politics, 25:3 (1993), pp. 275-296. 
${ }^{8}$ As argued in the editors' afterword in Lawrence Black, Hugh Pemberton and Pat Thane (eds), Reassessing 1970s Britain (Manchester MUP 2013), pp. 256-7.

${ }^{9}$ Francis Pym as recorded in Lord Hailsham, Notes on a meeting of the Shadow Cabinet, 11 April 1975, https://www.margaretthatcher.org/document/111134, accessed 5 November 2018.

${ }^{10}$ Tony Benn, Against the Tide. Diaries, 1973-76 (1989), p. 405.

${ }^{11}$ For more on the party during this period, Patrick Seyd, The Rise and Fall of the Labour Left (1987) and Leo Panitch and Colin Leys, The End of Parliamentary Socialism (2001).

${ }^{12}$ Benn, Against, pp. 188, 216, 303.

${ }^{13}$ Sheri Berman, 'Ideational Theorising in the Social Sciences since "Policy Paradigms, Social Learning and the State"', Governance 26:2 (2012), p. 227-9

${ }^{14}$ Hall, 'Social learning', p. 288-9.

${ }^{15}$ Berman, 'Ideational Theorising', pp. 224-5.

${ }^{16}$ E.P. Thompson, 'The moral economy of the English crowd in the eighteenth century', Past and Present 50 (1971), pp. 77-8.

${ }^{17}$ Bob Jessop and Ngai-Ling Sum, 'Pre-disciplinary and Post-disciplinary Perspectives', New Political Economy, 6:1 (2001), p. 97.

${ }^{18}$ Anne Swidler, 'Culture in action: symbols and strategies', American Sociological Review 51:2 (1986), pp. 276-8. 273, 284.

${ }^{19}$ Stuart Hall, 'The Great Moving Right Show' in Stuart Hall and Martin Jacques (eds), The Politics of Thatcherism (1983)

${ }^{20}$ Dean Blackburn, 'Penguin Books and the "marketplace for ideas" in Black et al (eds), 1970s Britain, pp. 228-38. 
${ }^{21}$ J. Curran and J. Seaton, Power without Responsibility. The Press and Broadcasting in Britain (1981, ed.), p. 29; Paddy Scannell, 'The Dialectic of Time and Television', Annals of the American Academy of Political and Social Science, September 2009, Vol. 625, pp. 223-4.

${ }^{22}$ Central Statistical Office, Social Trends, No. 3, 1972 (HMSO, 1972), p. 103; M. Young and P. Wilmott, The Symmetrical Family (Harmondsworth, 1975), pp. 211213; Joe Moran, Armchair Nation. An Intimate History of Britain in front of the TV (2013), pp. 192, 202.

${ }^{23}$ Before 1972 this was the responsibility of the Independent Television Authority. Neither body had responsibility for the production of programmes.

${ }^{24}$ Alan O'Connor (ed.), Raymond Williams on Television (1989), p. 4.

${ }^{25}$ Dennis Potter, The Nigel Barton Plays (Harmondsworth, 1967), p. 21.

${ }^{26}$ Although even a talent show could articulate political values, see Joe Moran, '"Stand up and be counted": Hughie Green, the 1970s and Popular memory', History Workshop Journal 70 (2010), pp. 172-98.

${ }^{27}$ K. Kumar, 'Holding the Middle Ground: The BBC, the Public and the Professional Broadcaster', in J. Curran, M. Gurevitch and J. Woolacott (eds.), Mass Communication and Society (1977).

${ }^{28}$ Stuart Laing, Representations of Working-Class Life, 1957-1964 (1986).

${ }^{29}$ John Finch interview with the author, September $9^{\text {th }} 2013$. Finch wrote and produced Coronation Street while H.V. Kershaw who he called 'a true blue Tory' was executive producer. In the late 1960s Kershaw opposed Finch's suggestion of introducing black characters to the series. 
${ }^{30}$ Tony Garnett, The Day the Music Died (2016), p. 163.

${ }^{31}$ Stephen Hearst, Head of Television Arts Features: Television Weekly Programme Review meeting minutes, 26 February 1969, BBC Written Archive (BBCWA).

${ }^{32}$ See Stanton B. Garner, Trevor Griffiths. Politics, Drama, History (Ann Arbor, 1999) and Andy Willis, 'Jim Allen: radical drama beyond 'Days of Hope", Journal of British Cinema and Television, 5:2 (2008), pp. 300-317.

33 Times, 9 November 1981; Listener, 11 September 1975; Jacob Leigh, The Cinema of Ken Loach (2002), p. 104.

${ }^{34}$ Mike Poole and John Wyver, Powerplays. Trevor Griffiths in Television (1984), p. 1, 73; Garner, Griffiths, p. 99; Trevor Griffiths, Through the Night and Such Impossibilities (1977), Author's Preface, no page numbers.

${ }^{35}$ See for example, Milton Schulman, The Ravenous Eye (1975), p. 10.

${ }^{36}$ Lawrence Black, 'There Was Something About Mary: The National Viewers' and Listeners' Association and Social Movement History' in Nick Crowson, Matthew Hilton and James McKay (eds), NGOs in Contemporary Britain. Non-state Actors in Society and Politics since 1945 (2009).

${ }^{37}$ http://www.margaretthatcher.org/document/102777, accessed 3 February 2016. For Whitehouse, see http://tonygarnett.info/tg-at-the-bbc/mary-whitehouse-daysof-hope/, accessed 21 May 2018.

${ }^{38}$ Guardian, 18 August 1976.

${ }^{39}$ Helen Wheatley, 'Introduction: Re-viewing television histories' in her (ed), ReViewing Television History. Critical Issues in Television Historiography (2007), p. 1. ${ }^{40}$ Scannell, 'Dialectic', pp. 229-30, 231, 233. 
${ }^{41}$ Paddy Scannel and David Cardiff, A Social History of British Broadcasting: Volume One, 1922-1939, Serving the Nation (Oxford, 1991).

${ }^{42}$ Moran, Armchair, p. 11.

${ }^{43}$ David Kynaston, Modernity Britain: 1957-1962 (2015), p. 96.

${ }^{44}$ Christina von Hodenberg, Television's Moment. Sitcom Audiences and the Sixties Cultural Revolution (2015), p. 11. See also Lawrence Black, 'Whose finger on the button? British television and the politics of cultural control, Historical Journal of Film and Television, 25:4 (2005), p. 548 and Wheatley, 'Re-viewing', pp. 9-10. ${ }^{45}$ For example: Jean Seaton, Pinkoes and Traitors. The BBC and the nation, 19741987 (2015) and M.K. MacMurragh-Kavanagh, 'The BBC and the Birth of "The Wednesday Play", 1962-66: institutional containment versus "agitational contemporaniety', Historical Journal of Film, Radio and Television 17:3 (1997).

${ }^{46}$ For example: Jonathan Bignell, Stephen Lacy and Madeleine MacmurraghKavanagh (eds), British Television Drama. Past, Present and Future (2000); John Caughie, Television Drama. Realism, Modernism and British Culture (Oxford, 2000); Lez Cooke, British Television Drama. A History (2003); and Charlotte Brunsdon, Law and Order (2010).

${ }^{47}$ Edward R. Brandt 'Trevor Griffiths' in his (ed), British Television Drama (1981), p. 72. See also the equally unjustified assertion that the 1960s women's liberation movement was partly inspired by TV drama, Janet Thumim, 'Women at work. Popular drama on British television, c.1955-60', in her (ed), Small Screens, Big Ideas. Television in the 1950s (2002), p. 220.

${ }^{48}$ Stuart Hood, On Television (1980), pp. 22-3. 
${ }^{49}$ John Corner, Critical Ideas in Television Studies (Oxford, 1999), pp. 80-1.

50 Janet Thumim, 'Introduction' Small Screens, p. 2. See also Margaret Scammel, 'Television and contemporary history', in Brian Brivati, Julia Buxton and Anthony Seldon (eds), The Contemporary History Handbook (Manchester, 1996), p. 414. As the leading US communications historian Lynn Spigel put it, the reconstruction of TV's impact on viewers' ideas was an 'elusive project', see her Make Room for TV: Television and the Family Ideal in Postwar America (University of Chicago Press, 1992), p. 187.

${ }^{51}$ Most notably, Gavin Schaffer, The Vision of a Nation. Making Multiculturalism on British Television, 1960-80 (Palgrave, 2014) and "Till Death Us Do Part" and the BBC: Racial Politics and the British Working Classes 1965-75', Journal of Contemporary History, 45:2 (2010); Rob Waters, 'Black Power on the Telly: America, Television, and Race in 1960s and 1970s Britain', Journal of British Studies 54 (October 2015); and von Hodenberg, Television's Moment.

${ }^{52}$ Schaffer, Vision, pp. 2, 275.

${ }^{53}$ Schaffer, Vision, p. 108.

${ }^{54}$ Schaffer, Vision, p. 950.

${ }^{55}$ None of ITV's franchises have made their papers public but Schaffer consulted some of the IBA's small number of surveys into especially controversial programmes, Schaffer, Vision, pp. 209-10.

${ }^{56}$ On the origins of the panel, Robert Silvey, Who's Listening? The Story of BBC Audience Research (1974). 
${ }^{57}$ That is the standard technique in contemporary audience research. Its absence meant the IBA and BBC surveys were usually deemed inconclusive about whether viewers were made more or less racist by watching certain controversial sitcoms, see Schaffer, Vision, p. 210.

${ }^{58}$ Indeed, in the case of letters sent to the IBA for the vast majority of ITV programmes they are their substitute, see Schaffer, Vision, 194.

${ }^{59}$ Schaffer, 'Racial Politics', p 466.

60 Television Weekly Programme Review meeting minutes, 22 October 1975.

${ }^{61}$ As does Waters, 'Black Power', 951-4, 957. Emphasis added.

${ }^{62}$ Suffragists often claimed their reading of certain texts made them embrace the cause. See Kabi Hartman, "'What made me a suffragette": the new woman and the new (?) conversion narrative', Women's History Review 12:1 (2003), pp. 36-8. For a general analysis on how converts reinterpret their biography see Peter L. Berger and Thomas Luckman, The Social Construction of Reality (Penguin, Harmondsworth, 1967), pp. 179-80.

${ }^{63}$ This is not to dismiss memory as a source. It has helped establish how far TV transformed post-war domestic routines: see Tim O'Sullivan, 'Television Memories and the Cultures of Viewing, 1950-65' in John Corner (ed), Popular Television in Britain (1991).

${ }^{64}$ Annebella Pollen, 'Research Methodology in Mass Observation Past and Present: 'Scientifically, about as valuable as a chimpanzee's tea party at the zoo'? History Workshop Journal, 75:1 (2013), pp. 213-35.

${ }^{65}$ Hodenberg, Television's Moment, p. 288. 
${ }^{66}$ Adrian Bingham, Family Newspapers? Sex, Private Life, and the British Popular Press 1918-1978 (Oxford, 2009), p. 3.

${ }^{67}$ Colin Hay, 'Narrating the crisis: the discursive construction of the "Winter of Discontent"', Sociology, 30:2 (1996). See also his 'Crisis and the structural transformation of the state: interrogating the process of change', British Journal of Politics and International Relations 1:3 (1999), pp. 317-44.

${ }^{68}$ Moran, Armchair, p. 239; Bingham, Family Newspapers?, p. 18.

${ }^{69}$ Listener, 31 May 1973.

${ }^{70}$ Schaffer, Vision, p. 205

${ }^{71}$ Schaffer, Vision, pp. 205, 238.

72 Waters, 'Black Power', p. 950.

${ }^{73}$ Henrik Ornebring, 'Writing the history of television audiences. The Coronation in the Mass-Observation Archive' in Wheatley, Re-Viewing.

${ }^{74}$ David Morley, Family Television. Cultural Power and Domestic Leisure (1986), p. 156. For an appreciation of Morley's work, see John Tulloch, Watching Television Audiences. Cultural Theories and Methods (2000), pp. 179-91.

${ }^{75}$ Silvo Lenart, and Kathleen M. McGraw, 'America Watches "Amerika:" Television Docudrama and Political Attitudes', Journal of Politics, 51:3 (1989), pp. 706, 710. ${ }^{76}$ Laurie Taylor and Bob Mullan, Univited Guests. The Intimate Secrets of Television and Radio (1986), p. 206.

77 Hodenberg, Television's Moment, pp. 84-5.

${ }^{78}$ Audrey Webb to Dennis Potter and Piers Haggard, 17 April 1978, Pennies from Heaven, Programme Files, BBCWA. 
79 Television Weekly Programme Review meeting minutes, 6 February 1974, BBCWA.

${ }^{80}$ Russell Davies (ed.), The Kenneth Williams Diaries (1993).

${ }^{81}$ See Stuart Jeffries, Mrs Slocombe's Pussy. Growing Up in Front of the Telly (2001) and Brian Viner, Nice to See It, To See It, Nice. The 1970s in front of the telly (2009).

82 In his history of television, Moran barely mentions them: see Armchair, pp. 236-7.

${ }^{83}$ As argued in Adrian Bingham, 'Ignoring the first draft of history?', Media History 18:3-4 (2012), p. 311.

${ }^{84}$ See for example Kevin Williams, Read All About It. A History of British Newspapers (2010), pp. 198-9; James Curran and Jean Seaton, Power without Responsibility. The Press and Broadcasting in Britain Power, (2010 ed.), pp. 88-90.

${ }^{85}$ Paul Rixon, TV Critics and Popular Culture (2011), p. 37.

${ }^{86}$ John Tulloch, Trevor Griffiths (Manchester, 2006), pp. 74-98.

${ }^{87}$ For an outline of the politics of the press during this period, see Adrian Bingham and Martin Conboy, Tabloid Century. The Popular Press in Britain, 1896 to the present (2015), pp. 77-88; James Thomas, Popular Newspapers, the Labour Party and British Politics (2005), pp. 61-86; and Mark Hollingsworth, The Press and Political Dissent (1986), especially the Introduction.

${ }^{88}$ Stuart Hall's Introduction to A.C.H. Smith, Paper Voices. The Popular Press and Social Change, 1935-1965 (1975) pp. 11-12, 20-1.

${ }^{89}$ Daily Telegraph, 16 July 1976.

${ }^{90}$ Martin Jackson worked as TV critic for the Conservative-supporting Daily Express and Daily Mail but was also Labour candidate in both 1974 general elections and a 
Kent County councilor: http://www.broadcastnow.co.uk/news/people/obituarymartin-jackson/5009343.article, accessed 9 September 2015.

${ }^{91}$ Daily Express, 25 January 1978.

92 Tribune, 6 and 13 August 1976.

${ }^{93}$ Irene Shubik, Play For Today: The Evolution of Television Drama (1975), p. 180.

${ }^{94}$ Manchester Evening News, 7 August 1976.

${ }^{95}$ Clive James, Visions Before Midnight (1981), pp. 128-9.

${ }^{96}$ Philip Purser, Done Viewing (1992), pp. 60-1, 130.

97 Janice Radway, Reading the Romance: Women, Patriarchy, and Popular Literature (1984).

${ }^{98}$ Purser, Done, p. 155.

${ }^{99}$ In its analysis of both papers' personae this section relies on Smith, Paper Voices, especially pp. 232-48.

${ }^{100}$ Quoted in Selina Todd, The People. The Rise and Fall of the Working Class, 19102010 (2014), p. 313. On the origins of the Mirror's populism, see Adrian Bingham and Martin Conboy, 'The Daily Mirror and the Creation of a Commercial Popular Language', Journalism Studies, 10:5 (2009), pp. 639-54.

${ }^{101}$ See Rixon, TV Critics, chapter 5.

102 Historians of film use publicity material in a similar way. See Jo Fox, 'Winston Churchill and the "Men of Destiny": Leadership and the role of the Prime Minister in wartime feature films' in Richard Toye and Julie Gottlieb (eds), Making Reputations. Power, Persuasion and the Individual in Modern British Politics (2005), pp. 92-108. 
103 Based on Joint Industry Committee for Television Audience Research figures published in The Stage and Television Today.

${ }^{104}$ See for example John Finch (ed.), Granada Television. The First Generation (Manchester, 2003).

105 Garner, Griffiths, p. 103. Poole and Wyver, Powerplays, p. 72-3.

${ }^{106}$ Tony Garnett, 'Working in the Field', in Sheila Rowbotham and Huw Beynon (eds), Looking at Class. Film, Television and the Working Class in Britain (2001), p. 77.

${ }^{107}$ For more on the series, see Shubik, Play For Today and Carl Gardner and John Wyver, 'The Single Play: From Reithian Reverence to Cost-accounting and Censorship', Screen 24:4-5 (1983), pp. 114-24.

108 Television Weekly Programme Review meeting minutes, 26 February 1969, BBCWA.

109 John Hill, Ken Loach. The Politics of Film and Television (2011), p. 148.

110 David Edgar, 'Ten Years of Political Theatre, 1968-78', Theatre Quarterly 8:32 (1979), p. 29.

${ }^{111}$ Daily Express, 5 July 1976.

112 Garnett, Music, p. 166; Hill, Loach, p. 154.

${ }^{113}$ See the debate about Days of Hope in Part IV of Tony Bennett, Susan BoydBoeman, Colin Mercer and Janet Woolacott (eds), Popular Television and Film (1981). For Griffiths, Poole and Wyver, Powerplays, pp. 96-9.

${ }^{114}$ Audience Research Department (ARD), 'Brassneck', VR/75/313, BBCWA.

115 Time Education Supplement, 25 June 1976. 
${ }^{116}$ Allen's work is discussed in Hill, Loach, pp. 80-103, 134-56 and Stephen Lacey, Tony Garnett, (Manchester, 2007), pp. 104-6.

${ }^{117}$ Radio Times, 6-12 September 1975.

118 Griffiths' work is discussed in Pool and Wyver, Powerplays, pp. 30-100; Garner, Griffiths, pp. 99-126.

119 Madeleine Macmurragh-Kavanagh, 'Too secret for words: coded dissent in female authored Wednesday Plays' in Bignell et al (eds), Television Drama, pp. 150-3.

${ }^{120}$ Shubik, Play for Today, p. 180; Macmurragh-Kavanagh, 'Too secret for words', pp. 154-5.

${ }^{121}$ Garner, Griffiths, pp. 119-20.

122 JICTAR, Weekly TV Audience Reports, British Film Institute Archive.

${ }^{123}$ This estimate is based on the number of households being 19 million and the average number in every household being 2.9: Social Trends 39 (HMSO, 2009), p. 14. ${ }^{124}$ This takes into account that in 197125.5 per cent of the population was sixteen or under - Office of National Statistics, Population. Social Trends 41 (HMSO, 2011), p. 11.

125 'Communication', p. 18.

${ }^{126}$ ARD, 'All Good Men', VR/74/77, BBCWA.

${ }^{127}$ ARD, 'The Big Flame', VR/69/(1)122, BBCWA.

${ }^{128}$ ARD, 'The Spongers', VR/78/52, BBCWA.

129 Financial Times, 4 September 1974.

${ }^{130}$ Smith, Paper Voices, pp. 237-8.

${ }^{131}$ Daily Mirror, 5 July 1976. 
132 TV Times, 5-11 and 12-18 June, 1976.

${ }^{133}$ Morning Star, 5 and 30 June 1976; Tribune, 30 July 1976.

${ }^{134}$ Daily Mirror, 14 June 1976 and 5 July 1976.

135 Quoted in Poole and Wyver, Powerplays, p. 94; Morning Star, 5 June 1976; TV

Times, 5-11 June, 1976.

${ }^{136}$ Guardian, 2 August 1976; Tulloch, Griffiths, p. 91.

137 TV Times, 1 July 1976.

${ }^{138}$ Daily Mirror, 4 February 1970.

${ }^{139}$ Daily Mirror, 20 February 1969. The 1966 Devlin Report called for the decasualisation of dock labour.

${ }^{140}$ Daily Mirror, 7 June 1976. Emphasis added.

${ }^{141}$ Daily Mirror, 19 July 1976.

142 Daily Mirror, 16 August 1976. Emphasis added.

${ }^{143}$ ARD, 'Days of Hope', episode one, VR/75/526 and 'Days of Hope', episode three, VR/75/552, BBCWA.

${ }^{144}$ Sunday Telegraph, 23 May 1971.

145 Daily Express, 20 February 1969.

${ }^{146}$ Daily Mirror, 20 February 1969.

147 Sunday Telegraph, 23 February 1969; Daily Mail, 10 February 1969; Lacey, Garnett, pp. 57-67.

${ }^{148}$ ARD, 'The Rank and File', VR/71/(1)190, BBCWA.

${ }^{149}$ Daily Telegraph, 27 September 1975.

${ }^{150}$ Daily Telegraph, 26 September and 3 October 1975. 
${ }^{151}$ Sunday Telegraph, 14 September 1975.

152 Garnet, Music, p. 215; Tribune, 17 October 1975 and Morning Star, 20 September 1975.

${ }^{153}$ Daily Mirror, 11 September 1975.

${ }^{154}$ Daily Mirror, 2 October 1975.

155 Daily Express, 2 September 1974.

${ }^{156}$ Daily Express, 25 September and 2 October 1975.

${ }^{157}$ Daily Express, 3 October 1975.

${ }^{158}$ Daily Express, 26 September 1975.

${ }^{159}$ Radio Times, 6-12 September 1975.

160 Garnett, Music, p. 136.

${ }^{161}$ Edgar, 'Political', pp. 29-30. This did not stop Edgar adapting his stage play

Destiny for broadcast in 1978.

162 Manchester Evening News, 3 July 1976.

163 'Communication', p. 18.

${ }^{164}$ Daily Mail, 23 and 26 September 1975.

165 On this issues, see Peter Mandler, 'The problem with cultural history', Cultural and Social History 1:1 (2004).

${ }^{166}$ Bingham, Family Newspapers?, pp. 3, 8-10.

${ }^{167}$ For the latest example of this research, see David Kirby, Emily Ekins, Alexander Coppock, 'The Long-lasting Effects of Newspaper Op-Eds on Public Opinion', Quarterly Journal of Political Science 13:1 (2018). 
${ }^{168}$ See Stanley Feldman and Lee Sigelman, 'The Political Impact of Prime-Time Television: "The Day After"', Journal of Politics, 47:2 (1985), pp. 571-2.

${ }^{169}$ Hall, 'Right Show', p. 29.

${ }^{170} \mathrm{Hay}$, 'Narrating the crisis' and his 'Crisis and the structural transformation of the state'.

${ }^{171}$ See in particular Mass-Observation, The Press and its Readers (1949) and Hulton Research, Patterns of British Life (1950).

${ }^{172}$ Hall, 'Moving Right', p. 28. 